\title{
PENYULUHAN HUKUM KESELAMATAN LALU LINTAS SEBAGAI STRATEGI MEWUJUDKAN BUDAYA PATUH HUKUM LALU LINTAS
}

\author{
Raja Desril*, Elviandri, Aksar, Raihana, Desi Sommaliagustina, \\ Tri Wahyuni Lestari \\ Program Studi Ilmu Hukum, Fakultas Hukum \\ Universitas Muhammadiyah Riau \\ email: rajadesril15@gmail.com
}

\begin{abstract}
Data on accidents and traffic violations collected by the Riau Regional Police Directorate and from our daily observations illustrates that the level of traffic safety and the level of community compliance with traffic laws / legislation is very alarming, if no strategic steps are taken. in order to increase the level of safety and increase the legal compliance of the community it will cause harm not only to the loss of life and property and psychological but also will cause losses in the economic field. The strategy or effort to increase legal awareness of the community as road users is basically part of orderly traffic. Strategies in increasing community legal awareness include: First, socialization or campaigns to comply with traffic regulations through the installation of banners and socialization. Second, Building the character of discipline. This character building can be started through the teacher's example. Therefore awareness of the instructional teachers is undoubtedly necessary. Security, order, safety and smooth traffic are shared responsibilities. Through this counseling, the character of discipline can be transmitted to all students of Muhammadiyah 3 Vocational School Pekanbaru.
\end{abstract}

Keywords: Safety, Traffic, Legal Compliance Culture

\begin{abstract}
Abstrak
Data kecelakaan dan pelanggaran lalu lintas yang dihimpun oleh Ditlantas Polda Riau serta dari pengamatan kita sehari-hari memberikan gambaran bahwa tingkat keselamatan lalu lintas dan tingkat kepatuhan masyarakat terhadap hukum / perundang-undangan lalu lintas sangat memprihatinkan, hal ini apabila tidak dilakukan langkah-langkah strategis guna meningkatkan tingkat keselamatan dan peningkatan kepatuhan hukum masyarakat maka akan menimbulkan kerugian bukan saja korban jiwa dan harta serta kejiwaan namun juga akan menimbulkan kerugian dibidang ekonomi. Strategi atau upaya meningkatkan kesadaran hukum masyarakat sebagai pengguna jalan pada dasarnya merupakan bagian dari tertib lalu lintas. Strategi dalam meningkatkan kesadaran hukum masyarakat diantaranya: Pertama, Sosialisasi atau kampanye untuk mematuhi peraturan lalu lintas melalui pemasangan spandukspanduk dan sosialisasi. Kedua, Membangun karakter disiplin. Pembanguna karakter ini bisa dimulai melalui keteladan guru. Oleh karena itu penyadaran kepada para guru menajdi niscaya dilakukan. Keamanan, ketertiban, keselamatan dan kelancaran lalu lintas merupakan tanggung jawab bersama. Melalui penyuluhan ini maka karakter disiplin bisa ditularkan kepada seluruh siswa/siswi SMK Muhammadiyah 3 Pekanbaru.
\end{abstract}

Kata Kunci: Keselamatan, Lalu Lintas, Budaya Patuh Hukum 


\section{PENDAHULUAN}

Setiap individu mengalami perubahan melalui serangkaian tahap perkembangan. Pelajar dalam hal ini masuk dalam tahap perkembangan remaja. Remaja, mengarahkan rasa ingin tahu yang tinggi ke arah hal-hal positif berupa kegiatan-kegiatan yang kreatif dan produktif adalah penting. Jika tidak, dikhawatirkan para remaja dapat terjerumus dalam kegiatan atau perilaku negatif, misalnya mencoba merokok dan narkoba, melanggar aturan lalu lintas, dan lain sebagainya (Soekanto, 2007: 101).

Pelanggaran lalu lintas merupakan salah satu keadaan dimana terjadi ketidaksesuaian antara aturan dan pelaksanaan. Aturan dalam hal ini adalah peranti hukum yang telah ditetapkan dan disepakati oleh negara sebagai undang-undang yang berlaku secara sah, sedangkan pelaksananya adalah manusia atau masyarakat suatu negara yang terikat oleh peranti hukum tersebut. Hal ini tertuang dalam UU RI Nomor 22 tahun 2009, yang di dalamnya berisi tentang lalu lintas dan angkutan jalan.

Tata tertib lalu lintas ditujukan untuk mewujudkan, mendukung, dan memelihara keamanan, keselamatan, ketertiban, dan kelancaran lalu lintas. Berbagai tindak penertiban terus diupayakan para polisi lalu lintas demi mewujudkan ketertiban lalu lintas dan kenyamanan berkendara, serta keselamatan para pengguna jalan raya, baik melalui razia kelengkapan berkendara, kelayakan mengemudi, serta kegiatan-kegiatan diskusi umum dengan tujuan meningkatkan ketertiban dalam berlalu lintas.

Dalam Undang-Undang Republik Indonesia Nomor 22 Tahun 2009 Pasal 77, secara jelas dikatakan bahwa setiap orang yang mengemudikan kendaraan bermotor di jalan wajib memiliki Surat Izin Mengemudi sesuai dengan jenis kendaraan bermotor yang dikemudikan, namun masih banyak pelajar yang belum layak untuk mengemudikan kendaraan bermotor kita temui di jalanan. Selain menimbulkan ketidaknyamanan berkendara bagi pengguna jalan yang lain, para pelajar yang sering berkendara sesuka hati ini juga beresiko mencelakai dirinya sendiri. Seringkali diberitakan dalam program- program berita baik ditelevisi maupun koran, tidak jarang kecelakaan yang melibatkan pengemudi usia pelajar menimbulkan korban jiwa. Peran serta orangtua dalam meminimalisir pelanggaran lalu lintas yang dilakukan oleh usia pelajar nampaknya masih minim, hal ini dapat dilihat dari masih banyaknya pelajar dibawah umur yang diberikan izin untuk mengemudikan motor tanpa memiliki SIM.

Fenomena pelajar yang belum layak mengemudi di jalan ini tidak jarang membuat pengguna jalan lainnya merasa terganggu dengan berbagai tindakan yang dilakukan terutama dalam hal etika berlalu lintas. Khususnya yang terjadi di SMA/SMK Muhammadiyah 3 Pekanbaru, kesadaran siswa dalam berlalu lintas nampak masih rendah, hal tersebut dapat dilihat dari banyaknya siswa yang membawa kendaraan bermotor tanpa memakai helm, padahal rute yang dilalui dari rumah ke sekolah melewati jalan kota. Pengetahuan yang minim mengenai peraturan lalu lintas dirasa adalah hal utama yang menyebabkan berbagai pelanggaran yang dilakukan oleh para pelajar saat ini.

Kenaikan jumlah pelanggaran yang dilakukan oleh usia pelajar ini tentunya memberikan kesan miris terhadap sikap para pelajar yang terkesan tidak memedulikan pentingnya keselamatan diri dalam berlalu lintas. Melalui wawancara langsung dengan seorang polisi lalu lintas Kota Pekanbaru, didapat informasi bahwa tindak 
pelanggaran yang umumnya dilakukan pelajar SMA/SMK adalah diantaranya, tidak memiliki SIM, tidak menggunakan helm, tidak mematuhi rambu lalu lintas, berboncengan melebihi kapasitas maksimal, modifikasi knalpot dan klakson motor. Pada usia remaja, ketaatan pada peraturan lalu lintas diharapkan timbul dari diri remaja sendiri. Remaja diharapkan menyadari mengapa harus mentaati peraturan lalu lintas. Pendidikan tentang keamanan dan keselamatan berlalu lintas perlu diberikan sejak dini, dengan membekali pengetahuan dan peraturan lalu lintas pada usia sekolah diharapkan dapat menumbuhkan kesadaran tertib dan disiplin berlalu-lintas, karena masa ini dianggap paling rawan dibandingkan dengan fase-fase perkembangan lainnya, dan merupakan suatu masa perkembangan yang berada diantara masa kanak-kanak dan dewasa.

Berkembangnya teknologi di bidang transportasi menambah jumlah kendaraan sehingga berpengaruh terhadap masyarakat di perkotaan dalam hal meningkatnya mobilitas masyarakat dalam berlalu lintas. Perilaku dan budaya berubah karena masyarakat cenderung lebih agresif, perilaku pengguna kendaraan bermotor seenaknya dalam berlalu lintas dapat menyebabkan stres dan perilaku agresif yang berujung menyebabkan pelanggaran berlalu lintas. Pelanggaran yang dilakukan oleh pengendara roda dua yang dimana banyak dilakukan oleh pelajar khususnya pelajar SMA/SMK untuk melakukan aktifitasnya sehari-hari. Sampel yang dipilih pada penelitian ini adalah siswa SMA/SMK kelas 3 yang rata-rata sudah cukup umur untuk memiliki SIM C. Salah satu faktor eksternal yang mempengaruhi para siswa SMA/SMK mengendarai sepeda motor tanpa atribut wajib yang lengkap adalah karena tidak adanya sanksi tegas dan dan kurangnya disiplin yang diberikan oleh orang tua. Salah satu bentuk pelanggaran dama mengendarai sepeda motor adalah siswa tidak mau menggunakan helm dan atribut keselamatan lainnya dalam mengendarai sepeda motor. Banyak dari mereka yang hanya menggunakan helm ketika ada razia kendaraan.

Menurut teori Eric Erikson terdapat 8 tahap perkembangan manusia, remaja berada dalam tahap ke lima yaitu adolesen yang dimulai pada usia 12-20 tahun. Adolesen ditandai dengan adanya kecenderungan identity-Identity Confusion. Sebagai persiapan ke arah kedewasaan didukung pula oleh kemampuan dan kecakapan-kecakapan yang dimilikinya dia berusaha untuk membentuk dan memperlihatkan identitas diri, ciri-ciri yang khas dari dirinya. Dorongan membentuk dan memperlihatkan identitas diri ini, pada para remaja sering sekali sangat ekstrim dan berlebihan, sehingga tidak jarang dipandang oleh lingkungannya sebagai penyimpangan atau kenakalan. Menurut Erikson masa ini merupakan masa yang mempunyai peranan penting, karena melalui tahap ini orang harus mencapai tingkat identitas ego, dalam pengertiannya identitas pribadi berarti mengetahui siapa dirinya dan bagaimana cara seseorang terjun ke tengah masyarakat.

Kaitannya dengan pelanggaran berkendara yang dilakukan oleh remaja merupakan salah satu bentuk ekstrim dari adanya dorongan membentuk dan memperlihatkan identitas diri, sehingga dibutuhkannya perhatian dari lingkungan sekitar untuk mengarahkan pengendara muda (siswa) untuk lebih disiplin berlalu lintas. Menurut Kamus Besar Bahasa disiplin memiliki arti tata tertib (di sekolah, kemiliteran, dsb); ketaatan (kepatuhan) kpd peraturan (tata tertib dsb); bidang studi yg memiliki objek, sistem, dan metode tertentu. 
Sedangkan berkendara memiliki arti duduk di atas sesuatu yg dinaiki, ditunggangi, dsb. Jadi, disiplin berkendara berarti tata tertib atau kepatuhan pada peraturan dalam mengendarai. Dalam KBBI motivasi berarti dorongan yg timbul pd diri seseorang secara sadar atau tidak sadar untuk melakukan suatu tindakan dengan tujuan tertentu; usaha yg dapat menyebabkan seseorang atau kelompok orang tertentu tergerak melakukan sesuatu krn ingin mencapai tujuan yangg dikehendakinya atau mendapat kepuasan dng perbuatannya.

Untuk mendukung keselamatan berlalu lintas yang dilaksanakan, maka sangat dibutuhkan adanya partisipasi masyarakat dan tidak kalah pentingnya adalah kesadaran masyarakat (guru) akan keselamatan berlalu lintas. Maka, dengan meningkatnya kesadaran hukum/kesadaran berlalu lintas para Guru SMK Muhammadiyah 3 Pekanbaru diharapkan dapat menjadi keteladanan bagi seluruh siswa/siswi SMK Muhammadiyah 3 Pekanbaru.

\section{METODE PENELITIAN \\ Permasalahan}

Dari latar belakang tersebut di atas maka penulis merumuskan permasalahannya yaitu terkait bagaimana membangun kesadaran dalam berlalu lintas dan bagaimana strategi dalam mewujudkan budaya patuh hukum lalu lintas.

\section{HASIL DAN PEMBAHASAN}

1. Lalu Lintas

Lalu lintas ditimbulkan oleh adanya pergerakan dari alat-alat angkutan, karena adanya kebutuhan perpindahan manusia dan atau barang. Karena itu, dampak yang tidak mungkin ditolak karena adanya pergerakan tersebut adalah terjadinya kecelakaan. Kecelakaan dapat disebabkan oleh faktor pemakai jalan (pengemudi dan pejalan kaki), faktor kendaraan dan faktor lingkungan (Pignataro, 1973). Pignataro juga menyatakan bahwa kecelakaan diakibatkan oleh kombinasi dari beberapa faktor perilaku buruk dari pengemudi ataupun pejalan kaki, jalan, kendaraan, pengemudi ataupun pejalan kaki, cuaca buruk ataupun pandangan yang buruk. Hobbs (1979) mengelompokkan faktor- faktor penyebab kecelakaan menjadi tiga kelompok, yaitu: faktor pemakai jalan (manusia), faktor kendaraan, faktor jalan dan lingkungan.

Dengan demikian, terdapat tiga faktor yang dapat menyebabkan tingginya angka kecelakaan lalu lintas, diantaranya adalah: Pertama, dan yang paling banyak menjadi faktor penyebab adalah faktor pengendara atau diri kita sendiri. Banyak kasus kecelakaan akibat pengendara yang ugal-ugalan dijalan, ada juga pengendara yang mengendarai dalam kondisi mengantuk, kurang fit, dan lain sebagainya. Kedua, faktor jalan, dibeberapa daerah masih banyak ditemukan jalan dengan kondisi rusak, berlubang, tidak rata, ataupun terlalu sempit sehingga menyebabkan jala mempunyai resiko kecelakaan tinggi. Ketiga, adalah faktor kendaraan. Kaca spion yang tidak dipasang lengkap, padahal kaca spion tersebut dibuat untuk mempermudah kita melihat kendaraan yang berada dbelakang kita. Kemudian knalpot yang diganti tidak standart akan membuat bising pengendara lainnya.

Dengan menggunakan Theory of Reasond Action atau TRA (Fishben \& Ajzen, 1980), yang kemudian disempurnakan dalam Theory Planned Behaviour atau TPB (Ajzen, 1985,1991) diharapkan mampu memahami perilaku berkendara secara baik. Teori ini dinilai tepat dalam menjelaskan pengaruh sikap dan motivasi dalam perilaku berkendara. Teori ini mengatakan bahwa intensi 
(niatan) dan penilaian adanya kontrol perilaku (perceived behavioral control) merupakan faktor-faktor penentu perilaku (Ajzen, 1991).

2. Pelanggaran Lalu Lintas

Ramdlon Naning (1983), menjelaskan bahwa yang dimaksud dengan pelanggaran lalu lintas jalan adalah perbuatan atau tindakan yang bertentangan dengan ketentuanketentuan peraturan perundangundangan lalu lintas. 22 Pelanggaran yang dimaksud diatas adalah sebagaimana diatur dalam Pasal 105 Undang-undang Nomor 22 tahun 2009 yang berbunyi: Setiap orang yang menggunakan Jalan Wajib: a. Berperilaku tertib; dan/atau b. Mencegah hal-hal yang dapat merintangi, membahayakan keamanan dan keselamatan lalu lintas dan angkutan jalan, atau yang dapat menimbulkan kerusakan jalan.

Pelanggaran, menurut Sudarto (1990:57) "perbuatan yang oleh umum baru disadari sebagai tindak pidana, karena undang-undang menyebutnya sebagai delik, jadi karena ada undangundang mengancam dengan pidana misalnya memparkir motor di sebelah kanan jalanan". Pengertian pelanggaran tersebut berbeda dengan pernyataan (Prodjodikoron 1981:28) yang mengartikan pelanggaran sebagai "Perbuatan melanggar sesuatu dan berhubungan dengan hukum berarti lain dari pada perbuatan melanggar hukum". Pelanggaran dalam hal ini tidak sama dengan kejahatan seperti yang dikemukakan oleh Soekanto (1990:51) mendeskripsikan pelanggaran lalu lintas sebagai masyarakat yang lalai: "siapakah pelanggar lalu lintas? Jawabannya bukanlah berkaitan dengan nama atau pekerjaanya. Penegak hukum harus menyadari bahwa pelanggaran lalu lintas (dalam kebanyakan hal) bukanlah penjahat, akan tetapi orang yang lalai atau alpa. Sudah tentu bahwa penegak hukum harus selalu siap menghadapi kenyataan, apabila pelanggarternyata adalah penjahat yang sedang melarikan diri. Akan tetapi, pada umumnya pelanggar adalah warga masyarakat yang lalai, oleh karena mengambil keputusan yang keliru".

Pelanggaran, menurut Sudarto (1990: 57) "perbuatan yang oleh umum baru disadari sebagai tindak pidana, karena undang-undang menyebutnya sebagai delik, jadi karena ada undang- undang mengancam dengan pidana misalnya memparkir motor di sebelah kanan jalanan." Pengertian pelanggaran tersebut berbeda dengan pernyataan (Prodjodikoron 1981: 28) yang mengartikan pelanggaran sebagai "perbuatan melanggar sesuatu dan berhubungan dengan hukum berarti lain dari pada perbuatan melanggar hukum".

Berdasarkan penjelasan yang telah dikemukakan di atas dapat ditarik kesimpulan bahwa pelanggaran adalah:

1. Perbuatan yang bertentangan dengan apa yang secara tegas dicantumkan dalam undang- undang pidana.

2. Pelanggaran merupakan tindak pidana yang lebih ringan dari kejahatan baik perbuatan maupun hukumannya.

Jika ketentuan tersebut diatas dilanggar maka akan dikualifikasikan sebagai suatu pelanggaran yang terlibat dalam kecelakaan. Untuk memberikan penjelasan tentang pelanggaran lalu lintas yang lebih terperinci, maka perlu dijelaskan lebih dahulu mengenai pelanggaran itu sendiri.

Dalam Kitab Undang-undang Hukum Pidana (KUHP) tindak pidana dibagi atas kejahatan (misdrijve) dan pelanggaran (overtredingen). Mengenai kejahatan itu sendiri dalam KUHP diatur pada Buku II yaitu tentang Kejahatan. Sedangkan pelanggaran diatur dalam Buku III 
yaitu tentang Pelanggaran. Dalam hukum pidana terdapat dua pandangan mengenai criteria pembagian tindak pidana kejahatan dan pelanggaran, yaitu bersifat kualitatif dan kuantitatif. Menurut pandangan yang bersifat kualitatif didefinisikan bahwa suatu perbuatan dipandang sebagai tindak pidana setelah adanya undang-undang yang mengatur sebagai tindak pidana. Sedangkan kejahatan bersifat recht delicten yang berarti suatu yang dipandang sebagai perbuatan yang bertentangan dengan keadilan, terlepas apakah perbuatan itu diancam pidana dalam suatu undang-undang atau tidak. Menurut pandangan yang bersifat kualitatif bahwa terhadap ancaman pidana pelanggaran lebih ringan dari kejahatan.

Menurut JM Van Bemmelen dalam bukunya "Handen Leer Boek Van Het Nederlandse Strafrecht" menyatakan bahwa perbedaan antara kedua golongan tindak pidana ini (kejahatan dan pelanggaran) tidak bersifat kualitatif, tetapi hanya kuantitatif, yaitu kejahatan pada umumnya diancam dengan hukuman yang lebih berat dari pada pelanggaran dan nampaknya ini didasarkan pada sifat lebih berat dari kejahatan. (Bambang Poernomo, 2002: 40).

Apabila pernyataan tersebut diatas dihubungkan dengan kenyataan praktek yang dilakukan sehari-hari dimana pemberian sanksi terhadap pelaku kejahatan memang pada umumnya lebih berat dari pada sanksi yang diberikan kepada pelaku pelanggaran. Untuk menguraikan pengertian pelanggaran, maka diperlukan para pendapat Sarjana Hukum. Menurut Wirjono Prodjodikoro (2003: 33), pengertian pelanggaran adalah "overtredingen" atau pelanggaran berarti suatu perbutan yang melanggar sesuatu dan berhubungan dengan hukum, berarti tidak lain dari pada perbuatan melawan hukum.
Sedangkan menurut Bambang Poernomo (2002:40) mengemukakan bahwa pelanggaran adalah politis-on recht dan kejahatan adalah crimineel- on recht. Politis-on recht itu merupakan perbuatan yang tidak mentaati larangan atau keharusan yang ditentukan oleh penguasa negara. Sedangkan crimineelon recht itu merupakan perbuatan yang bertentangan dengan hukum. Dari berbagai definisi pelanggaran tersebut diatas maka dapat disimpulkan bahwa unsur-unsur pelanggaran adalah sebagai berikut: 1.Adanya perbuatan yang bertentangan dengan perundangundangan 2.Menimbulkan akibat hukum Maka dari berbagai pengertian diatas maka dapat mengambil kesimpulan bahwa pelanggaran adalah suatu perbuatan atau tindakan yang bertentangan dengan ketentuan peraturan perundang-undangan. (Wirjono Prodjodikoro, 2003: 25).

Berpedoman pada pengertian tentang pelanggaran dan pengertian lalu lintas diatas, maka dapat diambil kesimpulan bahwa yang dimaksud dengan pelanggaran lalu lintas adalah suatu perbuatan atau tindakan yang dilakukan seseorang yang mengemudi kendaraan umum atau kendaraan bermotor juga pejalan kaki yang bertentangan dengan peaturan perundang-undangan lalu lintas yang berlaku. Ketertiban lalu lintas adalah salah satu perwujudan disiplin nasional yang merupakan cermin budaya bangsa karena itulah setiap insan wajib turut mewujudkannya. Untuk menghindari terjadinya pelanggaran lalu lintas maka diharapkan masyarakat dapat mengetahui dan melaksanakan serta patuh terhadap peraturan lalu lintas yang terdapat pada jalan raya.

3. Klasifikasi Pelanggaran Lalu Lintas Mengingat UU No. 14 Tahun 1992 telah digantikan oleh UUNo. 22 Tahun 
2009 tentang lalu lintas dan angkutan jalan, maka akan disebutkan klasifikasikan pelanggaran lalu lintas berdasarkan peraturan tersebut.

a. Mengemudikan kendaraan bermotor umum dalam trayek tidak singgah di terminal sebagaimana dimaksud dalam Pasal 276 Jo. Pasal 36 UULAJ.

b. Memasukkan kendaraan bermotor, kereta gandengan, dan kereta tempelan ke dalam wilayah Republik Indonesia, membuat, 27 merakit, atau memodifikasi kendaraan bermotor yang menyebabkan perubahan tipe, kereta gandengan, kereta tempelan, dan kendaraan khusus yang dioperasikan di dalam negeri yang tidak memenuhi kewajiban uji tipe. (Pasal 277 Jo. Pasal 50 ayat (1) UULAJ).

c. Mengemudikan kendaraan bermotor beroda empat atau lebih di Jalan yang tidak dilengkapi dengan perlengkapan berupa ban cadangan, segitiga pengaman, dongkrak, pembuka roda, dan peralatan pertolongan pertama pada kecelakaan. (Pasal 278 Jo. Pasal 57 ayat (3) UULAJ).

d. Mengemudikan kendaraan bermotor di jalan yang dipasangi perlengkapan yang dapat mengganggu keselamatan berlalu lintas. (Pasal 279 Jo. Pasal 58 UULAJ).

e. Mengemudikan kendaraan bermotor di jalan yang tidak dipasangi Tanda Nomor Kendaraan Bermotor yang ditetapkan oleh Kepolisian Negara Republik Indonesia. (Pasal 280 Jo. Pasal 68 ayat (1) UULAJ).

f. Orang yang mengemudikan kendaraan bermotor di jalan yang tidak memiliki Surat Izin Mengemudi. (Pasal 281 Jo. Pasal 77 ayat (1) UULAJ).

g. Pengguna jalan yang tidak mematuhi perintah yang diberikan oleh petugas Kepolisian Negara Republik Indonesia. (Pasal 282 Jo. Pasal 104 ayat (3) UULAJ).

h. Mengemudikan kendaraan bermotor di jalan secara tidak wajar dan melakukan kegiatan lain atau dipengaruhi oleh suatu keadaan yang mengakibatkan gangguan konsentrasi dalam mengemudi di jalan. (Pasal 283 Jo. Pasal 106 ayat (1) UULAJ).

i. Mengemudikan sepeda motor di jalan yang tidak memenuhi persyaratan teknis dan layak jalan yang meliputi kaca spion, klakson, lampu utama, lampu rem, lampu penunjuk arah, alat pemantul cahaya, alat pengukur kecepatan, knalpot, dan kedalaman alur ban. (Pasal 285 ayat. ayat (1) Jo. Pasal 106 ayat (3), Pasal 48 ayat (2) dan (3) UULAJ).

j. Mengemudikan kendaraan bermotor di jalan yang melanggar aturan perintah atau larangan yang dinyatakan dengan rambu lalu lintas. (Pasal 287 ayat (1) Jo. Pasal 106 ayat (4a) dan (4b) UULAJ).

k. Mengemudikan kendaraan bermotor di jalan yang melanggar aturan perintah atau larangan yang dinyatakan dengan alat pemberi isyarat lalu lintas. (Pasal 287 ayat (2) Jo. Pasal 106 ayat (4c) UULAJ).

1. Mengemudikan kendaraan bermotor di jalan yang melanggar aturan gerakan lalu lintas atau tata caraberhenti dan parkir. (Pasal 287 ayat (3) Jo. Pasal 106 ayat (4d) dan (4e) UULAJ).

$m$. Mengemudikan kendaraan bermotor di jalan yangmelanggar aturan batas kecepatan paling tinggi atau paling rendah. (Pasal 287 ayat (5) Jo. Pasal 106 ayat (4g) atau Pasal 115 a UULAJ).

n. Mengemudikan kendaraan bermotor di jalan yang tidak dilengkapi dengan Surat Tanda Nomor Kendaraan

Bermotor atau Surat Tanda Coba Kendaraan Bermotor yang ditetapkan oleh Kepolisian Negara Republik Indonesia. (Pasal 288 ayat (1) Jo. Pasal 106 ayat (5a) UULAJ).

o. Mengemudikan kendaraan bermotor di jalan yang tidak dapat menunjukkan Surat Izin Mengemudi yang sah. (Pasal 288 ayat (2) Jo. Pasal 106 ayat (5b) UULAJ). 
p. Mengemudikan dan menumpang kendaraan bermotor selain sepeda motor yang tidak dilengkapi dengan rumahrumah dan tidak mengenakan sabuk keselamatan dan mengenakan helm. (Pasal 290 Jo. Pasal 106 ayat (7) UULAJ).

q. Mengemudikan sepeda motor tidak mengenakan helm standar nasional Indonesia. (Pasal 29 ayat (1) Jo. Pasal 106 ayat (8) UULAJ).

r. Mengemudikan sepeda motor yang membiarkan penumpangnya tidak mengenakan helm. (Pasal 291 ayat (2) Jo. Pasal 106 ayat (8) UULAJ).

s. Mengemudikan kendaraan bermotor di jalan tanpa menyalakan lampu utama pada malam hari dan kondisi tertentu. (Pasal 293 ayat (1) Jo. Pasal 107 ayat (1) UULAJ).

\section{Kepatuhan Hukum}

Hukum mempunyai fungsi untuk memberikan perlindungan terhadap kepentingan manusia (seluruh manusia tanpa terkecuali).Oleh sebab itu maka hukum harus dilaksanakan agar kepentingan manusia dapat terlindungi. Dalam pelaksanaannya, hukum dapat berlangsung secara normal dan damai, akan tetapi dapat juga terjadi pelanggaran-pelanggaran hukum di dalam prakteknya.

Hal-hal yang digunakan sebagai pembenaran terhadap penerobosan hukumpun semakin banyak, salah satunya ialah kecendrungan munculnya semboyan yang menyatakan bahwa peraturan dan hukum dibuat untuk dilanggar.Sikap hormat terhadap hukumpun menjadi sangat sulit untuk dapat ditumbuhkan bila esensi taat hukumnya sudah terlanjur bergeser menjadi acuh hukum.Sikap mengacuhkan hukum ini bukanlah sepenuhnya kesalahan masyarakat, tetapi didukung dengan tidak efektifnya supermasi hukum di negeri ini. Beberapa faktornya penyebab pelanggaran peraturan ini antara lain, banyaknya aturan yang dibuat dengan tidak mempertimbangkan realitas di lapangan. Seperti yang terjadi di Jakarta, yaitu adanyaperaturan yang melarang mobil-mobil parkir di tepi jalan umum tertentu, namun tidak didukung dengan ketersediaan lahan parkir yang memadai.

Dapat diprediksi hal ini menjadi salah satu faktor yang melatarbelakangi keengganan masyarakat untuk mematuhi aturan, terkait dengan kurang realistisnya butir-butir aturan itu sendiri. Selain itu, faktor indisipliner dari penegak hukum dapat mendorong timbulnya pelanggaran hukum.Contoh sederhananya adalah saat supir bus menurunkan penumpangnya di wilayah yang terdapat lalu lintas dilarang berhenti. Alasan utama yang menjadikan hal tersebut adalah tidak adanya tindakan tegas dari aparat penegak hukum setempat. Berkaitan dengan hal itu, Rahardjo (2006: 81), mendefinisikan sebab ketidak pedulian masyarakat terhadap hukum menjadi 3 , yaitu:

1. Kurangnya sosialisasi dari pemerintah mengenai peraturan yang ada, baik peraturan lama maupun yang telah disempurnakan (baru). Minimnya pengetahuan masyarakat akan hukum, juga merupakan salah satu penyebab pelanggaran hukum, 2 . Hukum yang saat ini dirasakan terlalu bersifat kaku sehingga masyarakat seolah-olah diperlakukan sebagai robot yang didikte dalam melakukan berbagai kegiatan. Jika saja hukum mau bersifat lebih humanismaka masyarakat akan melaksanakan hukum dengan sepenuh hati tanpa adanya rasa keterpaksaan, sehingga dengan sendirinya mampu menimbulkan rasa hormat terhadap hukum, bukan karena denda,
3. Adanya presepi mengenai lemahnya kemampuan hukum untuk membuat hidup lebih tertib 
dikarenakan semakin maraknya politik suap dalam penyelesaian pelanggaran hukum.

Cacat hukum terjadi akibat ketidakmampuan dan ketidakmauan subjek hukum untuk melaksanakan aturan hukum yang berlaku. Hal ini kemungkinan berakar dari penanaman kultur yang terlanjur salah sejak awal dalam benamasyarakat. Misalnya saja adanya anggapan bahwa penggunaan helm hanyalah sebuah alat untuk menghindari pantauan polisi di jalan besar, bukan demi keselamatan pengendara.

Poin yang harus disadari oleh setiap orang, bahwa masing-masing aturan dibuat bukan tanpa pertimbangan, aturan dibuat untuk mengatur seluruh aspek kehidupan berbangsa dan bernegara yang pada akhirnya diharapkan akan berdampak baik secara langsung ataupun tidak langsung pada kehidupan bermasyarakat.

\section{Strategi Mewujudkan Budaya Patuh}

Hukum Lalu Lintas

Ketidakdisiplinan masyarakat pengguna jalan mencerminkan masih rendahnya antusias masyarakat untuk mematuhi peraturan berlalu lintas. Sementara disiplin berlalu-lintas tidak hanya semata-mata untuk kepentingan pihak kepolisian sebagai pelaksana penegak hukum, akan tetapi dalam penerapannya, tata tertib berlalu lintas dibuat untuk memenuhi kebutuhan dari masyarakat itu sendiri baik pengguna jalan maupun masyarakat yang di sekeliling ruas jalan agar terciptanya kehidupan yang aman dan tentram.

Dalam berlalu lintas, sering dijumpai masyarakat yang sudah mengetahui peraturan tetapi tidak melaksanakannya. Fenomena tersebut disebabkan adanya anggapan dari sebagian masyarakat yang menyatakan bahwa disiplin berlalu lintas tidak akan membawa keuntungan kepada masyarakat melainkan akan memperlambat aktivitas yang dilakukan oleh masyarakat itu sendiri. Ketidakpedulian sebahagian masyarakat tersebut menjadikan proses kegiatan berlalu lintas tidak terlaksana dengan tertib.

Sebenarnya, semakin tinggi kesadaran masyarakat akan hukum maka semakin memungkinkan adanya penegakan hukum di masyarakat. Karena hukum berasal dari masyarakat dan diperuntukkan mencapai kedamaian dimasyarakat pula. Oleh karena itu, dipandang dari sudut tertentu maka masyarakat dapat mempengaruhi penegakan hukum tersebut. Penegakan hukum berkaitan erat dengan ketaatan bagi pemakai dan pelaksana peraturan perundang-undangan terutama dalam berlalu lintas dengan tertib dan aman.

Tingginya angka lakalantas dengan 625 korban meninggal,

1.370 angka kecelakan dan 123.502 kasus pelanggaran lalu lintas sepanjang tahun 2015 (Dir. Lantas Polda Riau) harus menjadi perhatian serius semua elemen masyarakat khususnya di Bumi Lancang Kuning ini. Apalagi jumlah korban lakalantas termasuk anak-anak dan pelajar. Agar kedepan angka lakalantas terus menurun dan korbannya juga semakin sedikit.

Tertib lalu lintas dan menekan angka lakalantas bukan hanya tugas kepolisian saja, tetapi menjadi kewajiban kita semua. Disiplin berlalulintas harus menjadi budaya dan agenda penting kita sehari-hari. Ketika lakalantas dan pelanggaran masih banyak, mungkin aturan lalu lintas baru sekedar diketahui atau dimengerti saja. Namun masyarakat yang sudah sampai pada tahap mentaati apalagi menghargai, biasanya sudah paham apa tujuan dan manfaat dibalik aturan tersebut bagi dirinya. Misalnya aturan berhelm adalah demi keselamatannya. Begitupula dengan aturan-aturan yang lain. 
Strategi atau upaya meningkatkan kesadaran hukum masyarakat sebagai pengguna jalan pada dasarnya merupakan bagian dari tertib lalu lintas. Strategi dalam meningkatkan kesadaran hukum masyarakat diantaranya:

Pertama, Sosialisasi atau kampanye untuk mematuhi peraturan lalu lintas melalui pemasangan spanduk-spanduk dan sosialisasi ke sekolah-sekolah; Kedua, diadakannya Polsanak (Polisi Sahabat Anak), PKS (Patroli Keamanan Sekolah), Police Goes to Campus dan Taman Lalu Lintas. Ketiga, Membangun karakter disiplin. Pembanguna karakter ini bias dimulai melaui keteladan guru. Oleh karena itu penyadaran kepada para guru menajdi niscaya dilakukan. Kempat, Mengingatkan kembali kepada pemangku kebijakan mulai dari Dinas Pendidikan sampai kepada Kepala Sekolah agar kembali menggalakkan Nota Kesepakatan Menteri Pendidikan Nasional dengan Kepala Kepolisian Republik Indonesia Nomor: 03/III/KB/2010 dan Nomor B/III/2010 tanggal 8

Maret 2010 untuk memasukkan materi pendidikan lalu lintas dalam kurikulum intra kurikuler berupa kegiatan pengintegrasian disiplin berlalu lintas ke dalam kurikulum pendidikan dasar dan menengah. Masuknya kurikulum lalu lintas disekolah merupakan langkah positif untuk memberikan pemahaman kepada pelajar agar berhati-hati dijalan raya.

Pada dasarnya hukum itu adalah diri kita sendiri dan berbasis pada masyarakat, oleh karena itu hendaknya masyarakat pengguna jalan tidak hanya taat terhadap aturan lalu lintas pada saat ada petugas lalu lintas, tetapi juga taat pada saat tidak ada penjagaan, karena keamanan, ketertiban, keselamatan dan kelancaran lalu lintas merupakan tanggung jawab bersama.

\section{SIMPULAN}

Strategi atau upaya meningkatkan kesadaran hukum masyarakat sebagai pengguna jalan pada dasarnya merupakan bagian dari tertib lalu lintas. Strategi dalam meningkatkan kesadaran hukum masyarakatdiantaranya: Pertama, Sosialisasi atau kampanye untuk mematuhi peraturan lalu lintas melalui pemasangan spanduk-spanduk dan sosialisasi. Kedua, Membangun karakter disiplin. Pembanguna karakter ini bisa dimulai melalui keteladan guru. Oleh karena itu penyadaran kepada para guru menajdi niscaya dilakukan. Pada dasarnya hukum itu adalah diri kita sendiri dan berbasis pada masyarakat, oleh karena itu hendaknya masyarakat pengguna jalan tidak hanya taat terhadap aturan lalu lintas pada saat ada petugas lalu lintas, tetapi juga taat pada saat tidak ada penjagaan, karena keamanan, ketertiban, keselamatan dan kelancaran lalu lintas merupakan tanggung jawab bersama. Mari disiplin berlalulintas untuk keselamatan Bersama. Melalui penyuluhan ini maka karakter disiplin bisa ditularkan kepada seluruh siswa/siswi SMK Muhammadiyah 3 Pekanbaru.

\section{DAFTAR PUSTAKA}

[1] Ajzen, 1. (1985). From intentions to action: Atheory of planned behavior. In J. Kuhl \&J. Beckman (Eds.), Action control: Fromcognitions to behaviors (pp.11-39). New York: Springer.

[2] Ajzen, 1. (1991). The theory of planned behavior. Organizational Behaviour and Human Decision Processes.

[3] Barnadib, Imam. 1986. Filsafat Pendidikan. Yogyakarta: Andi Offset.

[4] Baron, R., \& Byrne, D. (2007). Psikologi sosial. Jakarta: Erlangga 
[5] Hobbs, 1979. Perencanaan dan Teknik Lalu Lintas. Gadjah Mada University Press, Yogyakarta.

[6] Lieb, R., a. Wiseman, F. (2001). Public attitudes toward automobile safety issues. Transportation Jounal.

[7] Lukman Hakim dan Fathul Lubabin Nuqul, Analisa Sikap Terhadap Aturan Lalu-Lintas Pada Komunitas Bermotor, Jurnal Psikologi Indonesia2011, Vol. VIII, No. 2, 93-103,

[8] Pignataro, L. J. 1973. Traffic Engineering Theory and Practice, Prentice Hall, Inc, Englewood Cliffs. New Jersey.

[9] Saksono.1994. Polisi dan Lalu Lintas. Bandung. Mandar Maju.

[10] Santoso,G.A., \& Maulani,D. (2009). Perilaku berlalu lintas di kota besar: Bandung, Jakarta dan Surabaya. The Role of Psychology In Indonesian Contemporary Society(p. 12). Jakarta: Fakultas Psikologi Universitas Indonesia

[11] Sarwono,S.W.2004. Psikologi remaja. Edisi revisi 8. Jakarta: Raja Grafindo Pustaka, 2004.

[12] Sears, D.O., Feedman, J.L, \& Peplau, L.A.1994. Psikologi Sosial. Edisil Keduabelas. Jakarta: Kencana.

[13] Warpani, S.P, 2002, Pengelolaan Lalu Lintas dan Angkutan Jalan, ITB, Bandung. 